\title{
The significance of vitamin $d$ receptor gene polymorphisms for susceptibility to hepatocellular carcinoma in subjects infected with Hepatitis CVirus
}

\begin{abstract}
Background: Vitamin D has emerging roles in fibrogenesis, cell cycle arrest, immune modulation, and tumorigenesis. Several single nucleotide polymorphisms (SNPs) in vitamin D receptor (VDR) gene are associated with tumorigenesis in various organs.
\end{abstract}

Objective: to investigate the association between the VDR gene polymorphisms and Hepatocellular carcinoma (HCC) risk and severity in Egyptian patients with chronic hepatitis $\mathrm{C}(\mathrm{CHC})$.

Methods: Five hundred thirty outpatients with chronic hepatitis $\mathrm{C}$ virus $(\mathrm{HCV})$ infection were initially enrolled, of which 180 patients with $\mathrm{CHC}, 180$ patients with liver cirrhosis and 170 patients with HCC. Another 170 age- and sex-matched healthy controls were enrolled. Genotyping of VDR gene at BsmI, ApaI and TaqI loci was performed. Evaluation of clinicopathological features of HCC was done. Data were analyzed using SPSS software (Version 17.0)

Results: HCC patients had significantly higher frequencies of ApaI CC genotype and bAt[CCA]-haplotype than non-HCC patients. Patients carrying ApaI C allele, ApaI CC genotype or bAt[CCA]-haplotype had significantly higher prevalence of $\mathrm{HCC}$, advanced stage of liver cirrhosis and lower serum 25-hydroxy vitamin D3 concentrations. Also, after adjusting other covariates (age, gender, platelets count, and serum $\infty$-fetoprotein and vitamin D levels), patients carrying ApaI CC genotype or bAt[CCA]-haplotype had significantly higher risk for HCC development.

Conclusion: The present study provided significant associations of VDR gene SNPs (ApaI CC genotype and bAt.CCA-haplotype) with HCC development and disease severity in $\mathrm{HCV}$-infected Egyptian patients. Thus, the determination of these VDR genetic variants in $\mathrm{HCV}$ patients could help identification of patients at-risk of HCC development.

Keywords: Vitamin D receptor gene; bAt[CCA]-Haplotype; single nucleotide polymorphisms; chronic hepatitis $\mathrm{C}$; hepatocellular carcinoma
Volume 7 Issue 4 - 2017

\author{
Mohammed Amin Mohammed,' Nesreen \\ Moustafa Omar, ${ }^{2}$ Soad Amin Mohammed, ${ }^{3}$ \\ Ahmed Galal Deiab! \\ 'Department of Internal Medicine, Gastroenterology, \\ Hepatology and Endoscopy Unit, Mansoura University, Egypt \\ ${ }^{2}$ Department of Histology and Cell Biology, Faculty of Medicine, \\ Mansoura University, Egypt \\ ${ }^{3}$ Department of Microbiology,Al-Azhar University, Egypt
}

Correspondence: Mohammed Amin Mohammed, Assistant Professor of Internal Medicine, Gastroenterology, Hepatology and Endoscopy Unit, Faculty of Medicine, Mansoura University, Mansoura, Ahmad Maher Street, 6th October Street, Postal Zip code: 355 I I; Egypt, Tel 0020 I I22022900; 0020 I00 I 409982; 002050294 I497,Email liver2345@gmail.com

Received: July 14, 2017 | Published: September 0I, 2017

\section{Introduction}

Vitamin D has pivotal immunomodulatory actions and emerging roles in hepatic pathophysiology, inflammatory and metabolic liver diseases. It is considered as a systemic hormone that is involved in metabolism, immune regulation, fibrogenesis and cancer development through its actions on Vitamin D receptor (VDR), an intracellular nuclear hormone receptor; subfamily 1 , group1, member 1 (NR111) which interacts with target genes producing a variety of biological conformational changes. ${ }^{1}$ VDR gene is located on chromosome 12q13.11; highly polymorphic contains eleven exons and spans about $75 \mathrm{~kb}^{2}$ Also, it has been previously well established that vitamin D exerts an array of tissue and cell specific antitumor activities.e.g. cell cycle arrest, cell adhesions, inhibition of cancer cell invasion, antiproliferation, pro-apoptosis, anti-angiogenesis, pro-differentiation on many cancer cells expressing VDR. ${ }^{3}$ Vitamin D-binding protein (DBP) and 25-hydroxy-vitamin D3 (25-OHD3) are mainly synthesized in the liver. Vitamin D has many direct effects on the liver (e.g. antifibrotic and expression of detoxifying enzymes). An association has been established between low levels of vitamin D3 and several diseases including viral hepatitis and cancer development. Low serum levels of 25-OHD3 were proved to be associated with increased liver fibrosis in patients with non-alcoholic steatohepatitis ${ }^{4}$ and type 2 diabetes mellitus ${ }^{5}$ and reported to be associated with high risk of HCC development. ${ }^{6}$ Moreover, the serum level of 25-OHD3 had been reported to affect the natural course and treatment response of chronic hepatitis C. ${ }^{7}$ Higher vitamin D concentrations were proved to be associated with better prognosis and improved outcomes of adverse health problems. ${ }^{8}$ Despite the reported mechanisms supporting the beneficial effects of Vitamin D3 supplementation, the total benefits of its supplementation remain ambiguous.

Chronic HCV infection is a major health problem worldwide that is complicated by liver cirrhosis and ultimately by HCC. Hepatocellular carcinoma is one of the most common and highly malignant cancers worldwide with high incidence in Sub-Saharan Africa and Eastern Asia. ${ }^{10}$ The carcinogenesis of HCC is a complex, multifactorial and multistep process. HCC has a very bad prognosis and restricted treatment options. There are multiple risk factors which contribute to hepatic carcinogenesis and HCC development including chronic hepatitis $\mathrm{C}(\mathrm{CHC})$ or chronic hepatitis $\mathrm{B}(\mathrm{CHB})$, liver cirrhosis, carcinogen exposure (dietary aflatoxin), and chronic alcohol ingestion. ${ }^{11}$ 
Single-nucleotide polymorphisms (SNPs) of VDR gene may deregulate the activity of vitamin $\mathrm{D}$, affecting the cancer risk. It has been reported that SNPs in the VDR gene are associated with tumorigenesis in various organs such as prostate, ${ }^{12}$ breast, ${ }^{13}$ skin, ${ }^{14}$ colon and rectum, ${ }^{15}$ and kidneys ${ }^{16}$ but these observations are conflicting and debatable. ${ }^{17}$ The interaction between VDR gene polymorphisms and vitamin D status has a pivotal role in cancer prognosis. ${ }^{18}$ Previous epidemiological studies showed that individual's susceptibility to cancer is mediated by a variety of genetic factors. ${ }^{19}$ The pathogenic mechanisms of genetic factors gene polymorphisms of cytokines, growth factors, and receptors relating chronic HCV to HCC development are not entirely well established. ${ }^{20}$ VDR gene polymorphisms have been described in several chronic liver diseases such as liver cirrhosis, ${ }^{21}$ autoimmune hepatitis, ${ }^{22}$ primary sclerosing cholangitis $^{23}$ and primary biliary cirrhosis. ${ }^{24}$ Moreover, it has been reported that there is a significant association between polymorphisms of VDR gene and the occurrence of HCC in alcoholic liver cirrhosis in Caucasian subjects, ${ }^{25}$ in HBV-infected patients ${ }^{26}$ and even in patients with chronic $\mathrm{HCV}^{27}$ However, the data in the literature describing the possible association between VDR gene polymorphisms and hepatocellular carcinoma (HCC) development are scarce and inconclusive especially in patients infected with HCV. Hence, the aim was to investigate VDR gene polymorphisms as a risk for HCC development in Egyptian subjects with chronic HCV infection.

\section{Patients and methods}

\section{Subjects}

Five hundred thirty (530) adult consecutive Egyptian outpatients attending department of internal medicine at Mansoura University Hospital with a confirmed diagnosis of hepatitis $\mathrm{C}$ virus infection and receiving long-term follow-up were initially enrolled in this study. Another One hundred seventy (170) age- and sex-matched healthy controls subjects were also enrolled. The age range was $18-70$ years. Male to female ratio was $1.28 ; 393 / 307$. The study was initiated in the October 2014 and continued through 2017. The study was approved by the Ethical Commission and Institutional review board of Mansoura Faculty of Medicine in Egypt (MFM-IRB; Code No: R/16.02.36). A written informed conscious consent was obtained from all participants before their participation. The inclusion criterion was the diagnosis of chronic hepatitis C. All patients were HCV positive. Exclusion criteria: Age below 18 years and over 70 years, a history of cancer of any type within the last 5 years, a history of solid organ transplantation or previous bone marrow transplantation, antiviral treatment and local or systemic tumor-specific treatment within the last month. Patients with chronic renal failure, bone disorders, thyroid disorders, intestinal malabsorption, previous gastrectomy, cardiac failure (ejection fraction $<50 \%$ ) and systemic infection (e.g. HIV, bacterial and fungal). Patients taking vitamin $\mathrm{D}$, calcium or antidepressant drugs. Other causes of liver disease (e.g. alcohol consumption, chronic hepatitis B or $\mathrm{D}$, primary biliary cirrhosis, metabolic liver disease, non-alcoholic steatohepatitis and autoimmune hepatitis).

\section{Methods}

Initially, all participants completed a detailed questionnaire regarding diet and habits and submitted to thorough history taking with detailed physical examinations and relevant medical history. At the day of study inclusion, three milliliters of venous blood were obtained from all participants and the serum samples were centrifuged at $3000 \mathrm{rpm}$ then aliquoted and stored at $-70^{\circ} \mathrm{C}$ until assayed. Laboratory parameters, Ultrasound, CT scans and MRI imaging model of end-stage liver disease (MELD score) and Child-Pugh scores were assessed at the time of inclusion in the study. ${ }^{28,29}$

Chronic hepatitis $\mathrm{C}$ was diagnosed by $\mathrm{HCV}$ antibody positive (third generation enzyme-linked immunosorbent assay; ELISA) and confirmed by qualitative HCV RNA polymerase chain reaction (PCR) AmplicorTM, Roch Diagnostics, Branchburg, NJ, USA. Serum HCV RNA level (Viral load) was detected using Real-Time PCR with COBAS TaqMan HCV Test (TaqMan HCV; Roche Molecular Systems Inc., Branchburg, NJ, USA; lower limit of detection: 15 IU/ $\mathrm{mL}){ }^{30}$

Liver cirrhosis was diagnosed by ascites, esophageal varices, fundic varices, splenomegaly, jaundice, imaging and liver biopsies (if available, according to modified-knodell histological activity index). ${ }^{31}$ HCC was diagnosed by 4-phase multi-detector computed tomography (CT) scan, dynamic contrast-enhanced magnetic resonance imaging (MRI) ${ }^{32,33}$ Diagnosis of HCC was confirmed if there is one of the following three items:

a. One or more of liver nodules $>1 \mathrm{~cm}$ in diameter in CT or MRI.

b. Early arterial enhancement with $\alpha$-fetoprotein $\geq 400 \mathrm{ng} / \mathrm{mL}$

c. Typical features of dynamic imaging (arterial phase hypervascularity and delayed phase washout) regardless $\alpha$-fetoprotein.

d. 25-Hydroxy vitamin D3 (25-OHD3) levels were measured using a 25-OH Vitamin D3 direct ELISA Kit intended for the quantitative determination of the 25-OHD in serum and fresh plasma (CRYSTAL CHEM, INC. Catalog. No: 09002, Assay range: $0-200 \mathrm{ng} / \mathrm{mL}$, Assay time $<2$ hours, Precision CV: $<10 \%$, Storage: $\left.2-8^{\circ} \mathrm{C}\right) .{ }^{34}$ Samples were measured in duplicates on a Tecan SLT Rainbow plate reader (Tecan, Männedorf, Switzerland).

\section{Detection of VDR gene polymorphisms}

Genomic DNA was prepared from 2 mLEDTA-collected peripheral blood leucocytes (stored at -80oC until use) either by salting out or using Qiagen protocol (Qiagen DNA isolation kit; Wizard Genomic DNA Purification kit, Promega Corporation, Madison, WI). Genotyping was performed using a commercial PCR-SSP Sequence-Specific Primer (Olerup SSP; One Lambda Inc., Canoga Park, California, USA). VDR genotypes were identified using PCR amplification followed by restriction fragment length polymorphisms (PCR-RFLP) assay. ${ }^{35}$ Two fragments of VDR gene were amplified. The Bs fragment (825base pair) and Ap fragment (745bp). They represent two regions of VDR gene. The Bs fragment contains the BsmI restriction site with a forward primer in exon 7 and a reverse primer in intron 8. The Ap fragment contains the ApaI and TaqI restriction sites with a forward primer in intron 8 and a reverse primer in exon $9 .{ }^{36}$ The primer sequences of VDR polymorphisms at the three loci were shown in Table 1 . The PCR mix contained $5 \mu \mathrm{L}$ of each primer $(10 \mathrm{pmol}), 5 \mu \mathrm{L}$ buffer, $1.5 \mu \mathrm{L} \mathrm{MgCl} 2(50 \mathrm{mM}), 5 \mu \mathrm{L}$ template DNA (50-100ng), $5 \mu \mathrm{L}$ dNTPs $(2 \mathrm{mmol} / \mathrm{L}), 2 \mu \mathrm{L}$ Taq polymerase (MBI Fermentas, St. LeonRot, Germany) and $26.5 \mu \mathrm{L}$ H2O. A total of 40 cycles of PCR were performed in a PTC-100-60 (M.J. Research, Watertown, MA, USA). An initial denaturation of DNA template at $95^{\circ} \mathrm{C}$ for 2 min followed by a denaturation step for $45 \mathrm{sec}$ at $94^{\circ} \mathrm{C}$, an annealing step for 45 sec at optimum temperature $\left(60^{\circ} \mathrm{C}\right.$ for Bs fragment and $67^{\circ} \mathrm{C}$ for the Ap fragment) and an extension reaction at $72^{\circ} \mathrm{C}$ for $1 \mathrm{~min}$. After last PCR cycle, a final extension step for 2 min at $72{ }^{\circ} \mathrm{C}$ was added. ${ }^{37}$ The amplified products were then digested with BsmI, ApaI and TaqI 
restriction endonucleases overnight at $37^{\circ} \mathrm{C}$, electrophoresed on $2 \%$ horizontal agarose gel, stained with $0.5 \mathrm{mg} / \mathrm{mL}$ of ethidium bromide and visualized under UVB-illumination using the E-Gel Precast Agarose Electrophoresis System (Invitrogen Life Technologies, PA4 9RF Paisley, UK) ${ }^{38}$ The presence or absence of the desired length of PCR products determined the allelic type. The presence of BsmI, ApaI or TaqI restriction sites was defined by the lower-case ' $b$ ', ' $a$ ', or' $t$ ' respectively. Their absence was defined by the upper-case 'B', 'A', or ' $T$ ' respectively. Digestion with BsmI restriction endonuclease resulted in two fragments of $650 \mathrm{bp}$ and $175 \mathrm{bp}$. Digestion with Apal restriction endonuclease produced two fragments of $531 \mathrm{bp}$ and $214 \mathrm{bp}$ if the site of restriction was present. TaqI restriction resulted in three fragments of about 205, 290 and 245bp when TaqI polymorphic site is present and in two fragments of 245 and $495 \mathrm{bp}$ in the absence of a TaqI polymorphic site. The studied SNPs were selected on the basis of allele frequencies and functional of clinical applications. ${ }^{39}$ To improve validity and quality of genotyping, re-genotyping of $20 \%$ of samples were done by other laboratory personnel and there were no discrepancies in genotyping. Also, confirmation of genotyping of $10 \%$ randomly selected samples was done by DNA sequencing.

All participants were assigned to the following groups:

1. Control group: comprised 170 Healthy controls (age: $56.3 \pm 1.21$ years; Females/Males: 82/88).

2. Patients' group: comprised 530 patients with chronic HCV infection (age: 60.18 \pm 5.4 years; Females/Males: 225/305). This group was further subdivided according to the disease severity into the following three subgroups:

a. Chronic Hepatitis group (CH): comprised 180 patients with chronic hepatitis (age: $58.5 \pm 1.13$ years; Females/Males: 88/92).

b. Liver cirrhosis Group (LC): comprised 180 patients with liver cirrhosis (LC) (age: 60.15 \pm 1.02 years; Females/Males: 84/96).

c. Hepatocellular carcinoma Group (HCC): comprised 170 patients with HCC (age: 62.0 1.39 years; Females/Males: 53/117).

\section{Statistical analysis}

Data were analyzed using SPSS software (Version 17.0, SPSS Inc., Chicago, IL). Quantitative (continuous) data were expressed as (Mean \pm Standard Deviation) while qualitative data and categorical variables were expressed as number and percentage. Categorical variables were compared using the chi-square $\left(\chi^{2}\right)$ test or Fisher's exact test. Subgroups were compared using the Mc-Nemar test. OneWay Analysis Of Variance (ANOVA) followed by Post-Hoc Tukey's honest significant difference (HSD) test was applied for multiple comparisons. ardy-Weinberg (H-W) equilibrium was used to assess the independent segregation of alleles. ${ }^{40}$ This $\mathrm{H}-\mathrm{W}$ equilibrium was then assessed using chi-square $\left(\chi^{2}\right)$ test or Fisher's exact test when appropriate. Allele frequency was calculated as the number of occurrences of the test allele in the population divided by the total number of alleles. Carriage rate was calculated as the number of individuals carrying at least one copy of test allele divided by the total number of individuals. Variables that achieved statistical significance with the univariate analysis were included in multiple regression analysis with a forward stepwise (likelihood ratio) to evaluate the independent factors associated with risk of HCC development. Also, the odds ratios (ORs) with $95 \%$ confidence intervals (CIs) of the association between HCC and genotypic frequencies were estimated using multiple logistic regression analysis after controlling for other covariates. ${ }^{41}$ For all statistical studies, $\mathrm{P}<0.05$ was considered to be statistically significant.

\section{Results}

Primer sequences of VDR polymorphisms at three loci of VDR gene were shown in Table 1 . The base change was $\mathrm{T} / \mathrm{C}(\mathrm{B} / \mathrm{b})$ for $\mathrm{BsmI}$, C/A (A/a) for ApaI and G/A (T/t) for TaqI. The Bs fragment contains the BsmI restriction site with one primer in exon 7 and the other in intron 8. The Ap fragment contains the ApaI and TaqI restriction sites with one primer in intron 8 (ApaI) and the other in exon 9 (TaqI).

The patient basic demographic, clinical and laboratory data in all studied groups were shown in Table 2 . HCC patients had a statistically significantly higher mean age than those of control patients $(\mathrm{P}=0.0064)$. The mean age of chronic hepatitis and liver cirrhosis patients was not significantly different from that of HCC patients. HCC patients had a statistically significantly higher male to female ratio than other groups ( $\mathrm{P}=0.023)$. Also, $\mathrm{HCC}$ patients had a statistically significantly lower platelets count, lower 25-Hydroxy-Vitamin D3, higher Serum alpha-fetoprotein, higher viral load and a more derangement of liver functions (ALT, AST, and serum albumin) than other groups $(\mathrm{P}<0.05$ for all). BMI and duration of $\mathrm{HCV}$ infection did not significantly differ among groups $(\mathrm{P}<0.05)$.

The distribution of Alleles, Genotypes frequencies of VDR gene polymorphism at BsmI, ApaI, and TaqI loci in the studied groups were demonstrated in Table 3. This distribution was in accordance with the Hardy-Weinberg equilibrium. Fisher's exact test was used to compare frequencies of HCC patients with each group. HCC patients had a statistically significantly higher frequency of ApaI CC genotype compared to control subjects $(\mathrm{P}=0.0009)$, patients with chronic hepatitis $(\mathrm{P}=0.0007)$, or liver cirrhosis $(\mathrm{P}=0.0004)$.

Table I Primer Sequences, product sizes, annealing temperatures and restrictions enzymes for VDR gene genotyping

\begin{tabular}{|c|c|c|}
\hline \multicolumn{3}{|c|}{ Single nucleotide polymorphisms (SNP) } \\
\hline \multirow{5}{*}{$\begin{array}{l}\text { Bsml (rs|5444|0); } \\
825 \text { base pair; bp }\end{array}$} & Forward primer & (5'-CAACCAAGACTCAAGTACCGCGTCAGTGA-3') \\
\hline & Reverse primer & (5'-AACCAGCGGAAGAGGTCAAGGG-3') \\
\hline & Exon and Intron & 7 and 8 respectively \\
\hline & Annealing temp & $61^{\circ} \mathrm{C}$ \\
\hline & Base change & $\mathrm{T} / \mathrm{C}(\mathrm{B} / \mathrm{b})$ \\
\hline \multirow{4}{*}{$\begin{array}{l}\text { Apal and Taql; } \\
745 \text { bp }\end{array}$} & \multirow{2}{*}{ Fragments } & If restriction site present: $825,650,175 \mathrm{bp}$ \\
\hline & & If restriction site absent: $650,175 \mathrm{bp}$ \\
\hline & Forward primer & (5'-CAGAGCATGGACAGGGAGCAA-3') \\
\hline & Reverse primer & (5'-GCAACTCCTCATGGCTGAGGTCTC-3') \\
\hline
\end{tabular}


Table continued..

\begin{tabular}{lll}
\hline Single nucleotide polymorphisms (SNP) & \\
\hline & Intron (Apal) & 8 \\
Apal ( rs7975232); & Annealing temp & $67^{\circ} \mathrm{C}$ \\
745 bp & Fragments & Apal: If restriction site present: 53I, 2 I4bp \\
& Exon (Taql) & 9, codon 252 \\
& Annealing temp. & $67^{\circ} \mathrm{C}$ \\
Taql ( rs73|236); & Base change & Taql: G/A (T/t) \\
745 bp & & Taql: If restriction site present: $205,290,245$ bp \\
& Fragments & Taql: If restriction site absent: 495,245 \\
\hline
\end{tabular}

Table 2 Baseline demographic and characteristic features of patients in all the studied groups

\begin{tabular}{|c|c|c|c|c|c|c|c|c|c|}
\hline & Control (170) & $\mathrm{CH}(180)$ & LC (I80) & HCC (170) & $\mathrm{CHC}(530)$ & ANOVA & & $\begin{array}{l}\text { Post-Hoc tul } \\
(\mathrm{a}, \mathrm{b}, \mathrm{c}, \mathrm{d}, \mathrm{e}, \mathrm{f})\end{array}$ & key test \\
\hline Group (Number) & Control & Group I & Group II & Group III) & $\begin{array}{l}\text { All patients } \\
\text { with CHC }\end{array}$ & F-statistics & P-value & $\begin{array}{l}\text { Significance } \\
\text { at }\end{array}$ & P-value \\
\hline Age (years) & $56.3 \pm 1.21$ & $58.5 \pm 1.13$ & $60.15 \pm 1.02$ & $62.0 \pm 1.39$ & $60.18 \pm 5.4$ & 4.107 & 0.0093 & c & 0.0064 \\
\hline Male/female: (ratio) & $88 / 82(1.07)$ & $92 / 88(0.82)$ & $96 / 84(1.14)$ & $117 / 53(2.21)$ & $305 / 225(1.36)$ & 3.155 & 0.0283 & cefh & 0.023 \\
\hline $\begin{array}{l}\text { Body mass index (BMI) } \\
\left(\mathrm{kg} / \mathrm{m}^{2}\right)\end{array}$ & $23.6 \pm 0.47$ & $23.4 \pm 0.59$ & $22.5 \pm 0.4$ & $22.76 \pm 0.467$ & $22.9 \pm 2.4$ & 1.097 & 0.3542 & - & $>0.05$ \\
\hline AST (U/L) & $40.6 \pm 1.0$ & $54.95 \pm 1.52$ & $95.8 \pm 3.17$ & $102.1 \pm 2.087$ & $83.72 \pm 23.48$ & 206.81 & $1.11 \mathrm{e}-16$ & abcdegh & $<0.001$ \\
\hline ALT (U/L) & $44.45 \pm 1.57$ & $104.4 \pm 3.72$ & $103.0 \pm 1.8$ & $117.65 \pm 3.83$ & $108.19 \pm 15.97$ & $|24.3|$ & $1.11 \mathrm{e}-16$ & abcefg & $<0.001$ \\
\hline Platelets $\left(10^{4} / \mu \mathrm{L}\right)$ & $23.6 \pm 0.47$ & $15.28 \pm 0.49$ & $11.84 \pm 0.45$ & $10.88 \pm 0.63$ & $|2.78 \pm 3.3|$ & 126.83 & $1.11 \mathrm{e}-16$ & abcdeg & $<0.001$ \\
\hline Serum Albumin (g/dl) & $4.6 \pm 1.0$ & $3.95 \pm 1.5$ & $2.6 \pm 1.9$ & $2.1 \pm 2.08$ & $3.05 \pm 0.4 I$ & $147.8 \mid$ & $1.11 \mathrm{e}-16$ & bcdeg & $<0.001$ \\
\hline $\begin{array}{l}\text { Serum alpha-fetoprotein } \\
\text { level }(\mathrm{ng} / \mathrm{mL})\end{array}$ & $9.52 \pm 0.6$ & $54.95 \pm 1.52$ & $67.35 \pm 5.11$ & $2,040.9 \pm 93.95$ & $701.48 \pm 499.31$ & 458.66 & $1.11 \mathrm{e}-16$ & cefgh & $<0.001$ \\
\hline $\begin{array}{l}\text { 25-Hydroxy-Vitamin } \\
\text { D3 (ng/ mL) }\end{array}$ & $31.88 \pm 1.82$ & $27.19 \pm 1.5$ & $21.7 \pm 1.06$ & $21.72 \pm 1.06$ & $24.2 \pm 6.4$ & 11.99 & $9.40 \mathrm{e}-07$ & bcdegh & $<0.01$ \\
\hline $\begin{array}{l}\text { Duration of HCV } \\
\text { infection (months) }\end{array}$ & - & $54.95 \pm 1.52$ & $56.0 \pm 2.44$ & $60.8 \pm 2.77$ & $58.7 \mid \pm 3.54$ & 1.832 & 0.1694 & - & $>0.05$ \\
\hline Log HCV-RNA (IU/mL) & - & $5.48 \pm 0.05$ & $5.77 \pm 0.08$ & $5.91 \pm 0.11$ & $5.68 \pm 0.39$ & 6.373 & 0.003 & eh & $<0.01$ \\
\hline
\end{tabular}

Data were expressed as mean \pm standard deviation; LC, liver cirrhosis; HCC, hepatocellular carcinoma; CHC, chronic hepatitis C;AST, aspartate transaminase;ALT,

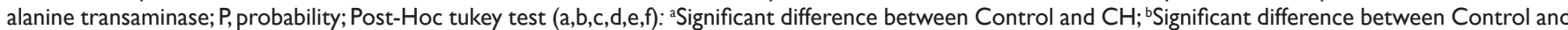

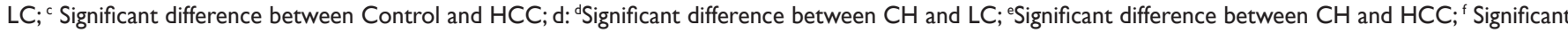
difference between $\mathrm{LC}$ and $\mathrm{HCC}$; 8 Significant difference between $\mathrm{CHC}$ and control; ${ }^{\mathrm{h}}$ Significant difference between $\mathrm{CHC}$ and $\mathrm{HCC}$.

Table 3 Alleles, Genotypes frequencies of VDR gene polymorphism at Bsml, Apal, and Taql loci in all studied groups.

\begin{tabular}{|c|c|c|c|c|c|c|c|c|c|}
\hline & & \multirow{2}{*}{$\begin{array}{l}\text { All patient (530) } \\
n(\%)\end{array}$} & \multirow{2}{*}{$\begin{array}{l}\mathrm{HCC}(170) \\
n(\%)\end{array}$} & \multicolumn{2}{|c|}{ Non-HCC (LC: 180, CH: I 80) } & \multirow{2}{*}{$\begin{array}{l}\text { Control (170) } \\
\mathrm{n}(\%)\end{array}$} & \multicolumn{3}{|c|}{ Fisher's exact test } \\
\hline & & & & LC n(\%) & $\mathrm{CH}$ n (\%) & & PI & $\mathbf{P 2}$ & P3 \\
\hline & $\mathrm{TT}(\mathrm{BB})$ & $0(0)$ & $0(0)$ & $0(0)$ & $0(0)$ & $0(0)$ & & & \\
\hline \multirow[t]{3}{*}{ Bsml } & $\mathrm{TC}(\mathrm{Bb})$ & $53(10)$ & $15(8.8)$ & $25(13.9)$ & $13(7.2)$ & $20(11.8)$ & NS & NS & NS \\
\hline & $\mathrm{CC}(\mathrm{bb})$ & $477(90)$ & $155(9 \mid .2)$ & $155(86.1)$ & 167(92.8) & $150(88.2)$ & NS & NS & NS \\
\hline & $\mathrm{T} / \mathrm{C}(\mathrm{B} / \mathrm{b})$ & $53 / 1007$ & $15 / 325$ & $25 / 335$ & $13 / 347$ & $20 / 320$ & NS & NS & NS \\
\hline \multirow[t]{5}{*}{ Apal } & CC (AA) & $309(59.3)$ & $120(70.6)$ & $94(52.22)$ & $95(52.78)$ & $92(54.12)$ & 0.0004 & 0.0007 & 0.0009 \\
\hline & $\mathrm{CA}(\mathrm{Aa})$ & $187(35.3)$ & $40(23.5)$ & $75(41.67)$ & $72(40)$ & $66(38.82)$ & 0.006 & 0.001 & 0.001 \\
\hline & AA (aa) & $34(5.6)$ & $10(5.9)$ & $I I(6 . I I)$ & $13(7.22)$ & $12(7.06)$ & NS & NS & NS \\
\hline & $\mathrm{C} / \mathrm{A}(\mathrm{A} / \mathrm{a})$ & $805 / 255$ & $280 / 60$ & $295 / 101$ & $262 / 98$ & $250 / 90$ & 0.012 & 0.003 & 0.007 \\
\hline & GG (TT) & $0(0)$ & $0(0)$ & $0(0)$ & $0(0)$ & $0(0)$ & 1 & 1 & 1 \\
\hline \multirow{3}{*}{ Taql } & $A G(T t)$ & $60(11.3)$ & $17(10)$ & $27(15)$ & $16(8.9)$ & $26(15.3)$ & NS & NS & NS \\
\hline & $\mathrm{AA}(\mathrm{tt})$ & $470(88.7)$ & $153(90)$ & $153(85)$ & I64(91.I) & |44(84.7) & NS & NS & NS \\
\hline & $\mathrm{G} / \mathrm{A}(\mathrm{T} / \mathrm{t})$ & $60 / 1000$ & $17 / 323$ & $27 / 333$ & $16 / 344$ & $26 / 314$ & NS & NS & NS \\
\hline
\end{tabular}

Fisher's exact test was used. P: Probability; PI, compares HCC and Liver Cirrhosis (LC); P2, Compares HCC and Chronic Hepatitis (CH); P3, Compares HCC and control; $\mathrm{CHC}$, chronic hepatitis $\mathrm{C} ; \mathrm{LC}$, liver cirrhosis; $\mathrm{HCC}$, hepatocellular carcinoma; $\mathrm{CH}$, chronic hepatitis; NS: Not significant $(\mathrm{P}>0.05)$. 
Also, the distribution of Haplotypes frequencies of VDR gene polymorphism consisting of ApaI C, BsmI C, and TaqI A alleles in the studied groups were demonstrated in Table 4. HCC patients had a statistically significantly higher frequency of CCAbAt-Haplotype compared to control subjects $(\mathrm{P}=0.0099)$, patients with chronic hepatitis $(\mathrm{p}=0.0003)$, or liver cirrhosis $(\mathrm{p}=0.003)$. HCC patients had a statistically significantly lower frequency of ApaI CA genotype $(\mathrm{P}<0.01)$ and $\mathrm{CAA}+\mathrm{TAG}[\mathrm{bat}+\mathrm{BaT}]-$ Haplotypes $(\mathrm{P}<0.05)$ than other groups. For other single nucleotide polymorphisms (SNPs) at BsmI and TapqI loci, there were no significant associations $(\mathrm{P}>0.05$ for all)

The association between SNPs of VDR gene at BsmI, ApaI, and TaqI loci and disease severity in chronic HCV infection were demonstrated in Table 5. The carriage of ApaI CC genotype had a statistically significantly higher prevalence of HCC (120/309; 38.8\%) compared to ApaI CA genotype (40/187; 21.4\%, P<0.05), ApaI AA genotype $(10 / 34 ; 29.4 \%, \mathrm{P}<0.05)$ or ApaI CA plus AA genotypes $(50 / 187 ; 22.6 \%, \mathrm{P}=0.002)$ (Figure 1). Also, the carriage of CCA[bAt]Haplotype had a statistically significantly higher prevalence of $\mathrm{HCC}$ $(118 / 305 ; 38.7 \%)$ compared to CAA[bat] plus TAG[BaT]-Haplotypes $(48 / 201 ; 23.9 \%, \mathrm{P} 4=0.012)$ (Figure 2). The carriage of CAA[bat]Haplotype had a lower nonsignificant prevalence of HCC (22.4\%). On the other hand, BsmI and TaqI polymorphisms were not significantly related to disease severity $(\mathrm{P}=0.09, \mathrm{P}=0.125$ respectively).

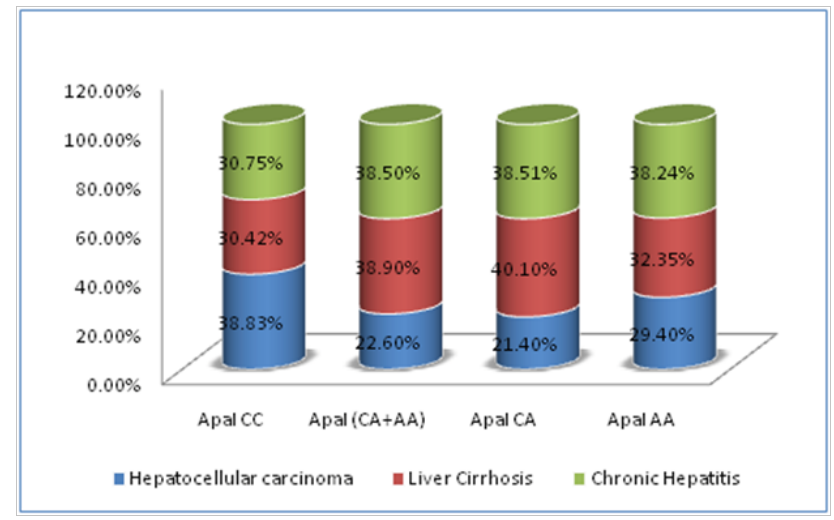

Figure I Correlations between different Apal genotypes of VDR gene and disease severity in chronic $\mathrm{HCV}$ infection.

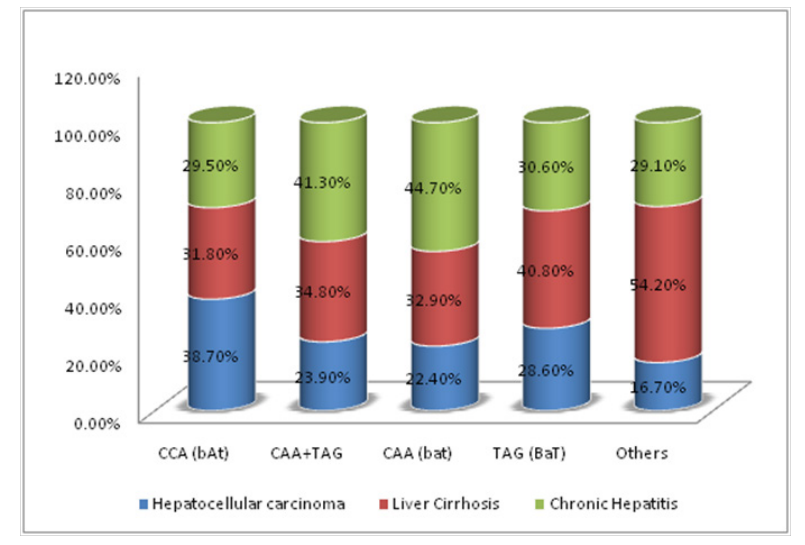

Figure 2 Correlations between different Bsml-Apal-Taql haplotypes of VDR gene and disease severity in chronic HCV infection.

Univariate analysis revealed that old age, male gender, lower platelets count, carriage of ApaI CC genotype and carriage of $\mathrm{CCA}[\mathrm{bAt}]$-haplotype were the factors significantly associated with HCC development. Multivariate logistic regression analysis was done after adjustment for age, sex, and platelets count to compare HCC and non-HCC patients with healthy control subjects (Table 6). There was a significant relationship between the carriage of ApaI CC genotype (using ApaI CA/AA as a reference), the carriage of ApaI C allele (using ApaI A allele as a reference) and the risk of HCC development. Also, there was a significant relationship between the carriage of $\mathrm{CCA}[\mathrm{bAT}]$-haplotype (using CAA/TAG[bAT]/BAT-haplotype as a reference) and the risk of HCC development. Comparing HCC to healthy controls, the adjusted OR (95\%CI, P-value) was 2.03 (1.3- 3.2, $\mathrm{p} 1=0.0018)$ for ApaI CC genotype, 1.7 (1.16- 2.4, P1=0.006) for ApaI C allele, 1.8 (1.14-2.85, P1=0.011) for CCA[bAT]-haplotype. Comparing non-HCC to healthy controls, the adjusted OR $(95 \% \mathrm{CI}$, $\mathrm{P}$-value was $2.17(1.47-3.2, \mathrm{p} 2=0.0001)$ for ApaI CC genotype and 2.01 (1.35-2.99, p2=0.0006) for CCA[bAT]-haplotype. Comparing HCC to non-HCC patients, the adjusted OR (95\% CI, P-value) was $0.46(0.31-0.68, \mathrm{p} 3=0.0001)$ for ApaI CC genotype, $0.58(0.417-$ $0.797, \mathrm{P} 3=0.0009)$ for ApaI $\mathrm{C}$ allele and $0.497(0.33-0.74, \mathrm{p} 3=0.0006)$ for $\mathrm{CCA}[\mathrm{bAT}]$-haplotype. On the other hand, there were no significant relationships between other SNPs (BsmI and TaqI) and the risk of HCC development $(\mathrm{P}>0.05)$.

Table $4 \mathrm{~N}=57$; Epidemiological distribution of the pathological fractures, traumatic fractures, and nonunion

\begin{tabular}{|c|c|c|c|c|c|c|c|c|c|}
\hline & & \multicolumn{2}{|c|}{ All patient (530) $\mathrm{HCC}(170)$} & \multicolumn{2}{|c|}{ Non-HCC (LC: I 80, CH: I80) } & \multirow{2}{*}{$\begin{array}{l}\text { Control ( } 170) \\
n(\%)\end{array}$} & \multicolumn{3}{|c|}{ Fisher's exact test } \\
\hline & & $n(\%)$ & $n(\%)$ & LC n(\%) & $\mathrm{CH}$ n(\%) & & $\mathbf{P I}$ & $\mathbf{P 2}$ & P3 \\
\hline \multirow{10}{*}{$\begin{array}{l}\text { Haplotypes } \\
\text { (Apal-Bsml-Taql) }\end{array}$} & $\mathrm{CCA}(\mathrm{bAt})$ & $305(57.5)$ & $118(69.4)$ & 97(53.9) & $90(50)$ & $94(55.3)$ & 0.003 & 0.0003 & 0.009 \\
\hline & CAA (bat) & $152(28.7)$ & $34(20)$ & $50(27.8)$ & $68(37.8)$ & $50(29.4)$ & 0.105 & $<0.00$ I & 0.059 \\
\hline & TAG (BaT) & $49(9.2)$ & $14(8.2)$ & $20(11.1)$ & $15(8.3)$ & $19(11.2)$ & NS & NS & NS \\
\hline & CAG (baT) & $10(1.9)$ & $2(1.2)$ & $4(2.1)$ & $4(2.2)$ & $4(2.4)$ & NS & NS & NS \\
\hline & TAA (Bat) & $6(1.1)$ & $2(1.2)$ & $3(1.7)$ & I (0.6) & $2(1.2)$ & NS & NS & NS \\
\hline & TCG (BAT) & $4(0.8)$ & $0(0)$ & $2(1.1)$ & $2(I . I)$ & $0(0)$ & NS & NS & NS \\
\hline & TCA (BAt) & $2(0.4)$ & $0(0)$ & $2(I . I)$ & $0(0)$ & I $(0.6)$ & NS & NS & NS \\
\hline & CCG (bAT) & $2(0.4)$ & $0(0)$ & $2(I . I)$ & $0(0)$ & $0(0)$ & NS & NS & NS \\
\hline & $\mathrm{CAA}+\mathrm{TAG}$ & 201 & 48 & 70 & 83 & 69 & 0.042 & 0.009 & 0.022 \\
\hline & $\mathrm{CCA} /(\mathrm{CAA}+\mathrm{TAG})$ & $305 / 201$ & $118 / 48$ & $97 / 70$ & $90 / 83$ & $94 / 69$ & 0.042 & $<0.00$ I & 0.022 \\
\hline
\end{tabular}


Table 5 Correlations between SNPs of VDR gene at Bsml,Apal, and Taql loci and disease severity in chronic HCV infection

\begin{tabular}{|c|c|c|c|c|c|c|}
\hline & & HCC (I70) & LC (180) & $\mathrm{CH}(180)$ & Total CHC (530) & p-value \\
\hline \multirow{2}{*}{ Bsml } & $\mathrm{TC}$ & $15(24.53 \%)$ & $25(47.17 \%)$ & I3(28.30\%) & $53(100 \%)$ & \multirow{2}{*}{$\mathrm{PI}=0.09$} \\
\hline & $\mathrm{CC}$ & $155(35.02 \%)$ & $155(32.49 \%)$ & $167(32.49 \%)$ & $477(100 \%)$ & \\
\hline \multirow{4}{*}{ Apal } & $\mathrm{CC}$ & $120(38.83 \%)$ & $94(30.42 \%)$ & $95(30.75 \%)$ & $309(100 \%)$ & \multirow{2}{*}{$P 2=0.0023$} \\
\hline & $\mathrm{CA}+\mathrm{AA}$ & $50(22.6 \%)$ & $86(38.9 \%)$ & 85 (38.5\%) & 221 (100\%) & \\
\hline & CA & $40(21.4 \%)$ & $75(40.10 \%)$ & $72(38.51 \%)$ & $187(100 \%)$ & \multirow{4}{*}{$P 3=0.125$} \\
\hline & $\mathrm{AA}$ & $10(29.4 \%)$ & II (32.35\%) & $13(38.24 \%)$ & $34(100 \%)$ & \\
\hline \multirow{2}{*}{ Taql } & AG & $17(28.33 \%)$ & $27(45 \%)$ & $16(28.33 \%)$ & $60(100 \%)$ & \\
\hline & $\mathrm{AA}$ & $153(32.55 \%)$ & $153(32.55 \%)$ & $164(34.89 \%)$ & $470(100 \%)$ & \\
\hline \multirow{5}{*}{ Haplotypes } & $\mathrm{CCA}(\mathrm{bAt})$ & 118 (38.7) & 97 (31.8\%) & $90(29.5 \%)$ & 305 (100\%) & \multirow{2}{*}{$P 4=0.012$} \\
\hline & $\mathrm{CAA}+\mathrm{TAG}$ & $48(23.9 \%)$ & $70(34.8 \%)$ & $83(41.3 \%)$ & $201(100 \%)$ & \\
\hline & CAA (bat) & $34(22.4 \%)$ & $50(32.9 \%)$ & $68(44.7 \%)$ & 152 (100\%) & \\
\hline & TAG (BaT) & $14(28.6 \%)$ & $20(40.8 \%)$ & $15(30.6 \%)$ & $49(100 \%)$ & \\
\hline & Others & $4(16.7 \%)$ & $13(54.2 \%)$ & $7(29.1 \%)$ & $24(100 \%)$ & \\
\hline
\end{tabular}

SNPs, single nucleotide polymorphisms; HCC, hepatocellular carcinoma; LC, liver cirrhosis; CH, chronic hepatitis; CHC, chronic hepatitis C; Chi-square was used to compare the carriage rate of genotypes in each SNPs of VDR gene. PI, Compare the Carriage Rate of BsmITC and CC Genotypes; P2, Compare the carriage rate of $A$ pal $C C$ and (CA+AA) genotypes; P3, Compare the carriage rate of Taql AG and AA genotypes; P4, Compare the carriage rate of CCA haplotype and (CAA+TAG) haplotypes

Table 6 Multivariate regression analysis of factors associated with HCC risk in patients with chronic HCV infection

\begin{tabular}{|c|c|c|c|c|c|c|c|c|c|c|}
\hline & & Control & HCC & Non-HCC & $\begin{array}{l}\text { HCC vs. } \\
\text { Control }\end{array}$ & & $\begin{array}{l}\text { Non-HCC vs. } \\
\text { Control }\end{array}$ & & $\begin{array}{l}\text { HCC vs. Non- } \\
\text { HCC }\end{array}$ & \\
\hline & & $\mathbf{N}(\%)$ & $\mathbf{N}(\%)$ & $\mathbf{N}(\%)$ & $\begin{array}{l}\text { Adjusted OR } \\
(95 \% \mathrm{Cl})\end{array}$ & $\begin{array}{l}\text { Adjusted } \\
\text { PI value }\end{array}$ & $\begin{array}{l}\text { Adjusted OR } \\
(95 \% \mathrm{CI})\end{array}$ & $\begin{array}{l}\text { Adjusted } \\
\text { P2 value }\end{array}$ & $\begin{array}{l}\text { Adjusted OR } \\
(95 \% \mathrm{Cl})\end{array}$ & $\begin{array}{l}\text { Adjusted P3 } \\
\text { value }\end{array}$ \\
\hline \multirow[t]{4}{*}{ Bsml } & $\mathrm{TC}$ & $20(11.76)$ & 15 (8.82\%) & 38 (10.56\%) & $1.00 *$ & & $1.00 *$ & & $1.00 *$ & \\
\hline & $\mathrm{CC}$ & I50(88.24) & I55(9|.|8) & 322 (89.44\%) & I.37(0.68-2.79) & 0.374 & I.I3(0.64-2) & 0.678 & $1.22(0.65-2.3)$ & 0.536 \\
\hline & $\mathrm{T}$ & $20(5.9)$ & $15(4.4)$ & $38(5.3)$ & $1.00 *$ & & $1.00 *$ & & $1.00 *$ & \\
\hline & $\mathrm{C}$ & $320(94.1)$ & $325(95.6)$ & $682(94.7)$ & $1.35(0.68-2.69)$ & 0.387 & I.I2(0.64-I.96) & 0.686 & $1.21(0.66-2.23)$ & 0.547 \\
\hline \multirow[t]{4}{*}{ Apal } & $\mathrm{CA}+\mathrm{AA}$ & $78(45.9)$ & 50 (29.4\%) & I7I (47.5\%) & $1.00 *$ & & $1.00 *$ & & $1.00 *$ & \\
\hline & $\mathrm{CC}$ & $92(54.1)$ & $120(70.6)$ & $189(52.5)$ & $2.03(1.3-3.2)$ & 0.0018 & $0.94(0.65-1.4)$ & 0.728 & $2.17(1.5-3.2)$ & 0.0001 \\
\hline & A & $90(26.5)$ & $60(17.6)$ & $195(27.1)$ & $1.00 *$ & & $1.00 *$ & & $1.00 *$ & \\
\hline & C & $250(73.5)$ & $280(82.4)$ & $525(72.9)$ & $1.7(1.16-2.4)$ & 0.006 & $0.969(0.724-\mid .3)$ & 0.834 & $1.73(1.25-2.4)$ & 0.0009 \\
\hline \multirow[t]{4}{*}{ Taql } & GA & $26(15.3)$ & $17(10)$ & 43 (11.9) & $1.00 *$ & & $1.00 *$ & & $1.00 *$ & \\
\hline & AA & |44(84.7) & I53(90) & $317(88.1)$ & $1.63(0.85-3.12)$ & & I.33(0.79-2.25) & 0.286 & $1.22(0.67-2.2)$ & 0.659 \\
\hline & G & $26(7.6)$ & $17(5)$ & $43(5.97)$ & $1.00 *$ & & $1.00 *$ & & $1.00 *$ & \\
\hline & A & $314(92.4)$ & $323(95)$ & 677(94.03) & I.57(0.84-2.96) & 0.1659 & $1.3(0.79-2.16)$ & 0.303 & $1.21(0.68-2.2)$ & 0.523 \\
\hline \multirow[t]{2}{*}{ Haploty } & CAA+TAG & $69(40.6)$ & $48(28.2)$ & $153(42.5)$ & $1.00 *$ & & $1.00 *$ & & $1.00 *$ & \\
\hline & CCA & $94(55.3)$ & $118(69.4)$ & |87(5|.9) & I.8(I.|4-2.85) & 0.011 & $0.897(0.62-|.3|)$ & 0.573 & $2.01(1.3-2.99)$ & 0.0006 \\
\hline
\end{tabular}

$\mathrm{PI}$ value represents the $\mathrm{HCC}$ compared to healthy controls; $\mathrm{P} 2$ value represents the non- $\mathrm{HCC}$ compared to healthy controls; $\mathrm{P} 3$ value represents the non- $\mathrm{HCC}$ compared to HCC patients; P value was adjusted for age, sex, and platelets count by logistic regression analysis; $\mathrm{HCC}$, hepatocellular carcinoma; Cl: Confidence Interval; OR: Odds Ratio. $\mathrm{P}$ is significant at $(\mathrm{P}<0.05)$; * Reference allele, genotype or haplotypes.

The comparisons between ApaI genotypes (ApaI CC vs. CA+AA) and [BsmI-ApaI-TaqI] Haplotypes (CCA vs. CAA+TAG) were shown in Table 7. Patients with ApaI CC genotypes and patients with $\mathrm{CCA}[\mathrm{bAT}]$-haplotype had a statistically significantly higher prevalence of HCC, pre-existing liver cirrhosis and a significantly lower serum 25-Hydroxy-Vitamin D3 concentrations ( $\mathrm{P}<0.05$ for all). $\mathrm{HCV}$ viral load did not significantly differ in patients carrying ApaI $\mathrm{CC}$ genotypes or $\mathrm{CCA}[\mathrm{bAT}]$-haplotype. Also, there was a higher but not significant ratio of BsmI and TaqI genotypes in patients carrying ApaI CC genotype and CCA haplotype $(\mathrm{P}>0.05)$. 
Table 7 Comparisons between different Apal Genotypes and between different Bsml-Apal-Taql Haplotypes of VDR Gene Polymorphisms in Patients with Chronic HCV Infection (530 patients)

\begin{tabular}{|c|c|c|c|c|c|c|}
\hline & \multicolumn{3}{|l|}{ ApaI genotypes } & \multicolumn{3}{|c|}{ BsmI-ApaI-TaqI haplotypes } \\
\hline & ApaI CC & ApaI (CA\&AA) & \multirow{2}{*}{ P-value } & CCA (bAt)-haplotype & Other haplotypes & \multirow{2}{*}{ P-value } \\
\hline $\mathrm{N}$ & 309 & 221 & & 305 & 225 & \\
\hline Age (years) & $56.5 \pm 4.4$ & $57.2 \pm 3.14$ & 0.139 & $59.2 \pm 3.5$ & $58.6 \pm 2.4$ & 0.337 \\
\hline Male gender N (\%) & $192 / 309(62 \%)$ & $113 / 221(51 \%)$ & 0.212 & $188 / 305(62 \%)$ & $117 / 225(52 \%)$ & 0.273 \\
\hline BMI $\left(\mathrm{kg} / \mathrm{m}^{2}\right)$ & $23 \pm 2.5$ & $22.7 . \pm 2.4$ & 0.059 & $22.9 \pm 2.4$ & $22.8 \pm 2.5$ & 0.138 \\
\hline AST (U/L) & $86 \pm 24$ & $84.5 \pm 26.3$ & 0.615 & $86.2 \pm 23.3$ & $80.4 \pm 23.4$ & 0.556 \\
\hline ALT (U/L) & $109.4 \pm 16.3$ & $106.5 \pm 15.4$ & 0.065 & $108.5 \pm 16.5$ & $105.3 \pm 15.6$ & 0.066 \\
\hline Platelets $\left(10^{4} / \mu \mathrm{L}\right)$ & $11.7 \pm 3.4$ & $12.97 \pm 3.2$ & 0.053 & $12.5 \pm 3.4$ & $13.1 \pm 3.1$ & 0.395 \\
\hline Log HCV-RNA (IU/mL) & $5.7 \pm 0.4$ & $5.68 \pm 0.37$ & 0.327 & $5.7 \pm 0.38$ & $5.7 \pm 0.39$ & 0.446 \\
\hline BsmI CC genotype & $297(96 \%)$ & $180(81 \%)$ & 0.221 & $285(93 \%)$ & $192(85 \%)$ & 0.482 \\
\hline TaqI AA genotype & $300(97 \%)$ & $170(77 \%)$ & 0.08 & $295(93 \%)$ & $175(93 \%)$ & 0.106 \\
\hline 25-OH-VITD (ng/mL) & $21.4 \pm 5.5$ & $26.3 \pm 6.1$ & 0.034 & $22.0 \pm 3.5$ & $25.8 \pm 6.6$ & 0.047 \\
\hline $\mathrm{HCC}$ & $120(39 \%)$ & $50(23 \%)$ & 0.005 & $118(39 \%)$ & $52(23 \%)$ & 0.007 \\
\hline $\mathrm{HCC}$ with underlying LC & $120(39 \%)$ & $28(13 \%)$ & $<0.0001$ & $118(39 \%)$ & $30(13 \%)$ & $<0.0001$ \\
\hline *Total LC patients & $214(69 \%)$ & $114(52 \%)$ & 0.044 & $215(70 \%)$ & $113(50 \%)$ & 0.021 \\
\hline
\end{tabular}

Data were expressed as mean \pm standard deviation or number (\%); LC, liver cirrhosis; HCC, hepatocellular carcinoma;AST, aspartate transaminase; ALT, alanine transaminase; AFP, serum alpha-fetoprotein level; 25-OH-VITD, 25-hydroxy-vitamin D3; BMI, body mass index; HCV, Hepatitis CVirus; P, probability; Chi-Square or Mann-Whitney U test were used. *Total LC patients (328) included I80patients with LC and I48 HCC patients with underlying LC.

\section{Discussion}

The carcinogenesis of HCC is a complex, multistep and multifactorial process. Chronic $\mathrm{HCV}$ infection, a major health problem worldwide, is ultimately complicated by HCC. ${ }^{20}$ Several genetic and epidemiological studies evidenced the pleiotropic feature of vitamin D. Recently, several VDR gene polymorphisms have been demonstrated in chronic liver diseases but with a so limited influence on the function and signaling of VDR protein. ${ }^{42}$ Also, there is scarcity in the data describing the possible association ion between VDR gene polymorphisms and HCC development. Therefore, studies are needed to clarify and understand the biological pathways, functional influences and consequences of these polymorphisms.

In this study, the possible association between VDR Gene polymorphisms and risk of HCC development in Egyptian populations infected with HCV was investigated. This study showed that patients with HCC had a significantly higher frequency of ApaI A allele, ApaI CC genotype and CCA[bAT]-Haplotype compared to control subjects $(\mathrm{P}<0.05)$. For BsmI and TapqI polymorphisms, there were no significant associations ( $\mathrm{p}>0.05$ for all).

Moreover, the implications of BsmI, ApaI, and TaqI polymorphisms on the severity of chronic liver diseases of HCV patients were also investigated in the current study. The carriage of either ApaI $\mathrm{CC}$ genotype or $\mathrm{CCA}[\mathrm{bAT}]-$ Haplotype had a significantly higher prevalence of HCC, pre-existing liver cirrhosis and a significantly lower serum 25-Hydroxy-Vitamin D3 concentrations (25-OHD) compared to other genotypes or haplotypes ( $\mathrm{P}<0.05$ for all). On the other hand, other SNPs polymorphisms (BsmI and TaqI) were not related to disease severity $(\mathrm{p}>0.09)$.

In addition to environmental, metabolic and viral factors, $V D R$ genes genetic polymorphisms have been related to chronic liver disease and HCC development. Many authors investigated the association of several polymorphisms in VDR gene with the severity of chronic liver disease. The commonest studied genetic variations in VDR gene were the FokI, BsmI, ApaI, TaqI, and bat-haplotypes consisting of BsmI, ApaI and TaqI. ${ }^{43,44}$ There are obvious ethnic and racial variations of allelic frequencies of these VDR gene polymorphisms in different hepatic and extrahepatic diseases. BsmI, ApaI, and TaqI SNPs are located in the 3'region of VDR gene in linkage disequilibrium with each other. These polymorphisms are implicated in modulation of several chronic liver diseases such as autoimmune hepatitis (FokI polymorphisms), primary biliary cirrhosis (BsmI polymorphism), primary sclerosing Cholangitis (ApaI polymorphisms) ${ }^{45}$ and viral hepatitis. ${ }^{46}$

Also, these VDR gene polymorphisms were reported to be associated with risk HCC development in patients with liver cirrhosis, ${ }^{47}$ chronic hepatitis $\mathrm{B},{ }^{48}$ alcoholic cirrhotic patients underwent liver transplantation ${ }^{25}$ and chronic hepatitis C. ${ }^{27}$ Huang et al. ${ }^{49}$ demonstrated that VDR gene polymorphisms at BsmI, ApaI, and TaqI were associated with distinct clinical phenotypes of hepatitis B carriers in Taiwanese patients but not with the risk of HCC suggesting a limited role of VDR gene polymorphisms in hepatocarcinogenesis. ${ }^{49}$ However, a biochemical evidence clearly indicated that HCC cells respond to the inhibitory effect of vitamin D and its analogs. ${ }^{50}$ Moreover, it had been reported that the antiproliferative effects of vitamin $\mathrm{D}$ against HCC cells correlate with intracellular VDR level. ${ }^{44,51}$ Also, it had been reported that polymorphism at FokI locus was associated with increased HCC susceptibility in Egyptian patients infected with chronic hepatitis B and had a significant role in the determination of its clinicopathological characteristics. ${ }^{48,26}$ VDR gene SNPs (ApaI CC genotypes, $\mathrm{CCA}[\mathrm{bAT}]$-haplotype and Taq AA genotype) were also reported to be significantly associated with high hepatitis $\mathrm{C}$ virus load but not with antiviral (peginterferon plus ribavirin) response in chronic HCV Asian patients. ${ }^{52}$ In our study, although HCC patients had significantly higher viral load than other groups, HCV viral load did not significantly differ in patients carrying ApaI CC genotypes or CCA[bAT]-haplotype.

Similar to the current study, both plasma vitamin D levels and VDR gene polymorphisms (ApaI CC genotype and bAt[CCA]haplotype) had been reported to be significantly associated with rapid fibrosis progression rate and the presence of cirrhosis.$^{53}$. Moreover, the current study further demonstrated a significant association with HCC development in CHC patients.

VDR gene polymorphism (bAt[CCA]--haplotype) was also reported to significantly impair the response to peginterferon/ribavirinbased therapy in patients with $\mathrm{HCV}$ and, similar to our results, could genetically predispose to low serum 25-OHD3 levels. ${ }^{54-56}$ 
Another study revealed that some genetic variations in binding protein $(G C), C Y P 2 R 1$, and $D H C R 7$ were associated with HCC progression in $\mathrm{HCV}$ patients and provided an evidence for a functionally relevant contribution of reduced serum 25-OHD3 concentrations to HCV-related HCC. ${ }^{57}$

Also, it had been previously reported that reduced serum levels of 25-hydroxy vitamin D3 were linked to the HCC development; nevertheless, the causal relationships remained ambiguous because of the small sample size of these studies or the false positive associations due to impaired liver functions at the date of HCC. ${ }^{57}$ Consistent with our results, some authors reported that VDR gene polymorphisms at ApaI locus had a role in HCC development in HCV-infected patients ${ }^{27}$. In this study, the significant association between polymorphisms in VDR gene which mediates and modulates vitamin D biological effects and HCV-related HCC could justify the causal relationships between genetic variations and distinct clinical phenotypes and suggest that an impaired vitamin D metabolism contributes to hepatocarcinogenesis in chronic hepatitis $\mathrm{C}$.

In this study, the clustering in specific haplotypes (bat-haplotypes consisting of BsmI, ApaI, and TaqI), estimations of 25-OHD plasma levels and the association with a specific tumor (HCC) and/or patient characteristics might increase the clinical relevance of VDR genotypes. However, it might become more relevant when associated with SNPs of other genes or enzymes involved in vitamin D metabolism, such as binding protein (GC) and CYP enzymes (CYP27A1, CYP27B1, CYP24A1, CYP2R1). ${ }^{18,58}$

So, further controlled clinical trials are justified to validate our observations and evaluate the impact of vitamin D supplementation on HCC risk and overall survival in patients with chronic HCV. Also, the influence of ethnicity on the distribution of VDR genetic polymorphisms associated with risk of HCC should be demonstrated in further studies.

\section{Conclusion}

The present study provided a significant association of VDR gene polymorphisms (ApaI CC genotype and bAt.CCA-haplotype) with HCC development and disease severity in HCV-infected Egyptian patients. Also, an evidence for a functionally relevant contribution of reduced serum levels of 25-hydroxy vitamin D3 to HCV-related HCC was demonstrated in this study. Thus, the determination of VDR genetic variations in HCV patients could help identification of patients at risk of HCC development.

\section{Acknowledgments}

Authors thank Prof. Dr. Salah El-Gamal, and Dr. Aya Mohammed Amin for their support and help.

\section{Conflicts of interest}

The authors declare no conflicts of interest

\section{Author contributions}

All the authors conceived, organized, drafted, reviewed, and approved the manuscript.

\section{Funding}

None.

\section{References}

1. Kamen DL, Tangpricha V. Vitamin D and molecular actions on the immune system:modulation of innate and autoimmunity. $J \mathrm{Mol} \mathrm{Med}$ (Berl). 2010;88(5):441-450.

2. Taymans SE, Pack S, Pak E, et al. The human vitamin D receptor gene (VDR) is localized to region 12 cen-q12 by fluorescent in situ hybridization and radiation hybrid mapping:Genetic and physical VDR map. J Bone Mineral Res. 1999;14(7):1163-1166.

3. Ting HJ, Yasmin-Karim S, Yan SJ, et al. A positive feedback signaling loop between ATM and the vitamin D receptor is critical for cancer chemoprevention by vitamin D. Cancer Res. 2012;72(4):958-968.

4. Barchetta I, Angelico F, Del Ben M, et al. Strong association between non alcoholic fatty liver disease (NAFLD) and low 25(OH) vitamin D levels in an adult population with normal serum liver enzymes. $B M C$ Med. 2011;9:85.

5. Takiishi T, Gysemans C, Bouillon R, et al. Vitamin D and diabetes. Endocrinol Metab Clin North Am. 2010;39(2):419-446.

6. Fedirko V, Duarte-Salles T, Bamia C, et al. Prediagnostic circulating vitamin D levels and risk of hepatocellular carcinoma in European populations: a nested case-control study. Hepatology. 2014;60(4):12221230.

7. Petta S, Camma C, Scazzone C, et al. Low vitamin D serum level is related to severe fibrosis and low responsiveness to interferon-based therapy in genotype 1 chronic hepatitis C. Hepatology. 2010;51(4):11581167.

8. Krishnan AV, Feldman D. Mechanisms of the anti-cancer and antiinflammatory actions of vitamin D. Annu Rev Pharmacol Toxicol. 2011;51:311-336.

9. Hajarizadeh B, Grebely J, Dore GJ. Epidemiology and natural history of HCV infection. Nat Rev Gastroenterol Hepatol. 2013;10(9):553-562.

10. Jemal A, Bray F, Center MM, et al. Global cancer statistics. CA Cancer J Clin. 2011;61(2):69-90.

11. El-Serag HB. Epidemiology of viral hepatitis and hepatocellular carcinoma. Gastroenterology. 2012;142(6):1264-1273.

12. Atoum MF, AlKateeb D, AlHaj Mahmoud SA. The Fok1 Vitamin D receptor gene polymorphism and 25(OH)D serum levels and prostate cancer among Jordanian men. Asian Pac J Cancer Prev. 2015;16(6):2227-2230.

13. Shaikh F, Baig S, Jamal Q. Do VDR Gene Polymorphisms Contribute to Breast Cancer? Asian Pac J Cancer Prev. 2016;17(2):479-483.

14. Orlow I, Reiner AS, Thomas NE, et al. Vitamin D receptor polymorphisms and survival in patients with cutaneous melanoma:a population-based study. Carcinogenesis. 2016;37(1):30-38.

15. Budhathoki S, Yamaji T, Iwasaki M, et al. Vitamin D Receptor Gene Polymorphism and the Risk of Colorectal Cancer:A Nested CaseControl Study. Plos one. 2016;11(10):e0164648.

16. Yang C, LI J, Li Y, et al. The vitamin D receptor gene ApaI polymorphism is associated with increased risk of renal cell carcinoma in Chinese population. Sci Rep. 2016;6:25987.

17. Vaughan-Shaw PG, O'Sullivan F, Farrington SM, et al. The impact of vitamin D pathway genetic variation and circulating 25-hydroxyvitamin D on cancer outcome:systematic review and meta-analysis. Br J Cancer. 2017;116(8):1092-1110.

18. Tagliabue E, Raimondi S, Gandini S. Vitamin D, Cancer Risk, and Mortality. Adv Food Nutr Res. 2015;75:1-52.

19. Wang P-R, Xu M, Toffanin S, et al. Induction of hepatocellular carcinoma by in vivo gene targeting. Proc Natl Acad SciUSA. 2012;109(28):1126411269. 
20. Ahmad J, Eng FJ, Branch AD. HCV and HCC:clinical update and a review of HCC-associated viral mutations in the core gene. Semin Liver Dis. 2011;31(4):347-355

21. Ramos-Lopez O, Martinez-Lopez E, Roman S, et al. Genetic, metabolic and environmental factors involved in the development of liver cirrhosis in Mexico. World J Gastroenterol. 2015;21(41):11552-11566.

22. Fan L, Tu X, Zhu Y, et al. Genetic association of vitamin D receptor polymorphisms with autoimmune hepatitis and primary biliary cirrhosis in the Chinese. J Gastroenterol Hepatol. 2005;20(2):249-255.

23. Kempinska-Podhorodecka A, Milkiewicz, M, Jabłonski D, et al ApaI polymorphism of vitamin D receptor affects health-related quality of life in patients with primary sclerosing cholangitis. PLoSONE. 2017;12(4):e0176264

24. Fang F, Wang J, Pan J, et al. Relationship between vitamin D $(1,25$ dihydroxyvitamin D3) receptor gene polymorphisms and primary biliary cirrhosis risk:a meta-analysis. Genet Mol Res. 2015;14(1):981-988.

25. Falleti E, Bitetto D, Fabris C, et al. Vitamin D receptor gene polymorphisms and hepatocellular carcinoma in alcoholic cirrhosis. World J Gastroenterol. 2010;16(24):3016-3024.

26. Peng Q, Yang S, Lao X, et al. Association of single nucleotide polymorphisms in VDR and DBP genes with HBV-related hepatocellular carcinoma risk in a Chinese population. Plos One. 2014;9:e116026.

27. Hung $\mathrm{CH}$, Chiu $\mathrm{YC}, \mathrm{Hu} \mathrm{TH}$, et al. Significance of vitamin d receptor gene polymorphisms for risk of hepatocellular carcinoma in chronic hepatitis C. Transl Oncol. 2014;7(4):503-507.

28. Kamath PS, Wiesner RH, Malinchoc M, et al. A model to predict survival in patients with end-stage liver disease. Hepatology. 2001;33(2):464 470.

29. Pugh RN, Murray-Lyon IM, Dawson JL, et al. Transection of the esophagus for bleeding oesophageal varices. Br J Surg. 1973;60(8):646649

30. Heid CA, Stevens J, Livak KJ, et al. Real time quantitative PCR. Genome Res. 1996;6(10):986-994.

31. Goodman ZD. Grading and staging systems for inflammation and fibrosis in chronic liver diseases. J Hepatol. 2007;47(4):598-607.

32. Liu PH, Hsu CY, Hsia CY, et al. ALBI and PALBI grade predict survival for HCC across treatment modalities and BCLC stages in the MELD Era. J Gastroenterol Hepatol. 2017;32(4):879-886.

33. Bruix J, Sherman M. American Association for the Study of Liver (2011) Management of hepatocellular carcinoma:an update. Hepatology. 2011;53(3):1020-1022.

34. Wielders JP, Wijnberg FA. Preanalytical stability of $25(\mathrm{OH})$-vitamin D3 in human blood or serum at room temperature:Solid as a rock. Clin Chem. 2009;55(8):1584-1585.

35. Fakruddin M, Mannan KS, Chowdhury A, et al. Nucleic acid amplification:Alternative methods of polymerase chain reaction. J Pharm Bioallied Sc. 2013;5(4):245-252.

36. Das B, Patra S, Behera C, et al. Genotyping of vitamin D receptor gene polymorphisms using mismatched amplification mutation assay in neonatal sepsis patients of Odisha, eastern India. Infect Genet Evol. 2016;45:40-47.

37. Cao L, Cui X, Hu J, et al. Advances in digital polymerase chain reaction (dPCR) and its emerging biomedical applications. Biosens Bioelectron. 2017;90:459-174.

38. Knapp LA. Single nucleotide polymorphism screening with denaturing gradient gel electrophoresis. Methods Mol Biol. 2009;578:137-151.

39. Wang TJ, Zhang F, Richards JB, et al. Common genetic determinants of vitamin D insufficiency:a genome-wide association study. The Lancet. 2010;376(9736):180-188
40. Crow Jf. Hardy Weinberg and language impediments. Genetics. 1999;152(3):821-825

41. Strano M, Colosimo BM. Logistic regression analysis for experimental determination of forming limit diagrams. International Journal of Machine, Tools and Manufacture. 2006;46(6):673-682.

42. Körner C, Riesner K, Krämer B, et al. TRAIL receptor I (DR4) polymorphisms $\mathrm{C} 626 \mathrm{G}$ and $\mathrm{A} 683 \mathrm{C}$ are associated with an increased risk for hepatocellular carcinoma (HCC) in $\mathrm{HCV}$-infected patients. $B M C$ Cancer. 2012;8(12):85.

43. Uitterlinden AG, Fang Y, Van Meurs JBJ, et al. Genetics and biology of vitamin D receptor polymorphisms. Gene. 2004;338(2):143-156.

44. Bandera-Merchan B, Morcillo S, Martin-Nuñez G, et al. The role of vitamin D and VDR in carcinogenesis:Through epidemiology and basic sciences. J Steroid Biochem Mol Biol. 2017;167:203-218.

45. Smyk DS, Orfanidou T, Invernizzi P, et al. Vitamin D in autoimmune liver disease. Clin Res Hepatol Gastroenterol. 2013;37(5):535-545.

46. Kitson MT, Roberts SK. D-livering the message:the importance of vitamin D status in chronic liver disease. J Hepatol. 2012;57(4):897909.

47. Nahon P, Zucman-Rossi J. Single nucleotide polymorphisms and risk of hepatocellular carcinoma in cirrhosis. J Hepatol. 2012;57:663-674

48. Mohammed MA, Shabana H, Sheta T, et al. Vitamin D Receptor Gene Polymorphisms as a predictive risk factor for Hepatocellular Carcinoma development and severity in chronic hepatitis B. Int $J$ Cancer Res. 2017;13(1):26-35

49. Huang YW, Liao YT, Chen W, et al. Vitamin D receptor gene polymorphisms and distinct clinical phenotypes of hepatitis B carriers in Taiwan. Genes Immun. 2010;11(1):87-93.

50. Pourgholami MH, Morris DL. 1,25-Dihydroxyvitamin D3 in lipiodol for the treatment of hepatocellular carcinoma:cellular, animal and clinica studies. J Steroid Biochem Mol Biol. 2004;89-90(1-5):513-518.

51. Dalhoff K, Dancey J, Astrup L, et al. A phase II study of the vitamin $\mathrm{D}$ analogue Seocalcitol in patients with inoperable hepatocellular carcinoma. Br J Cancer. 2003;89(2):252-257.

52. Hung $\mathrm{CH}, \mathrm{Hu} \mathrm{TH}, \mathrm{Lu} \mathrm{SN}$, et al. Association of vitamin $\mathrm{D}$ receptor gene polymorphisms with response to peginterferon plus ribavirin in Asian patients with chronic hepatitis C. J Formos Med Assoc. 2016;115(4):278-283.

53. Baur K, Mertens JC, Schmitt J, et al. Combined effect of 25-OH vitamin D plasma levels and genetic vitamin D receptor (NR 1I1) variants on fibrosis progression rate in HCV patients. Liver Int. 2012;32(4):635643.

54. Baur K, Mertens JC, Schmitt J, et al. The vitamin D receptor gene bAt (CCA) haplotype impairs the response to pegylated-interferon/ ribavirin-based therapy in chronic hepatitis $\mathrm{C}$ patients. Antivir Ther. 2012;17(3):541-547.

55. Garcia-Martin E, Agundez JA, Maestro ML, et al. Influence of vitamin D-related gene polymorphisms (CYP27B and VDR) on the response to interferon/ribavirin therapy in chronic hepatitis $\mathrm{C}$. PloSone. 2013;8(9):e74764

56. Abdelsalam A, Rashed L, Salman T, et al. Molecular assessment of vitamin $\mathrm{D}$ receptor polymorphism as a valid predictor to the response of interferon/ribavirin-based therapy in Egyptian patients with chronic hepatitis C. J Dig Dis.12016;7(8):547-553.

57. Lange CM, Miki D, Ochi H, et al. Genetic analyses reveal a role for vitamin D insufficiency in $\mathrm{HCV}$-associated hepatocellular carcinoma development. PLoS One. 2013;8(5):e64053.

58. Deeb KK, Trump DL, Johnson CS. Vitamin D signaling pathways in cancer:potential for anticancer therapeutics. Nat Rev Cancer. 2007;7(9):684-700. 